\title{
Different behaviour of mitochondrial and nuclear markers: introgression and the evolutionary history of Chrysocarabus (Coleoptera: Carabidae)
}

\author{
Andreas Düring, Martina Brückner \& Dietrich Mossakowski
}

Düring, A., Brückner, M. \& Mossakowski, D. 2006: Different behaviour of mitochondrial and nuclear markers: introgression and the evolutionary history of Chrysocarabus (Coleoptera: Carabidae). - Entomol. Fennica 17: 200-206.

Phylogenetic analyses of Chrysocarabus taxa using different markers result in different phylogenetic trees. In particular, the mitochondrial gene tree contradicts the results of morphological and inbreeding studies. Two very different haplotypes of Carabus splendens Olivier, 1790 do not form a clade within this phylogenetic tree. We have earlier proposed that contradictory results are due to introgression. To verify our hypothesis, we analysed the internal transcribed spacer 2. No substitutions were observed in these nuclear sequences between the individuals of Carabus splendens, which contain the different mitochondrial haplotypes in question. The differences in the gene trees based on mitochondrial and nuclear sequences can be explained with at least two introgression events.

A. Düring, M. Brückner and D. Mossakowski, Institute of Ecology \& Evolutionary Biology, University of Bremen, P.O. Box 330 440, D-28334 Bremen, Germany; correspondent author's e-mail:dmossa@uni-bremen.de

Received 12 January 2006, accepted 15 June 2006

\section{Introduction}

The taxon Chrysocarabus, a subgenus of Carabus, includes several taxa that seem to be very closely related, because of the occurrence of hybrids in the field (Puisségur 1964, Mossakowski et al. 1986, 1990). The number of species varies between seven and nine depending on the author. Further phylogenetic analyses of this subgenus based on (i) different morphological character complexes (Malausa et al. 1983, Mossakowski 1979, Marciniak 1995), (ii) cross breeding studies (Allemand \& Malausa 1984), (iii) allozyme variability (Braun 1988) and (iv) mitochondrial DNA sequences (Prüser 1996, Düring et al. 2001) resulted in different phylogenetic trees.

Contradictory results between trees inferred from different character sets are commonly encountered and may depend on different processes (see e.g., Maddison 1997). Incongruity between morphological taxonomy and results based on mitochondrial DNA data were described for the first time in the genus Carabus by Prüser (1996) for European species and by Su et al. (1996) for closely related species of the Japanese subgenus Ohomopterus. Su et al. (1996) interpreted their results by the assumption of parallel evolution, which resulted in so called "type switching". Sota and Vogler (2001) rejected the type switching hypothesis and demonstrated that the mechanism of incongruity was multiple introgression in their comprehensive molecular study.

In Chrysocarabus, Prüser (1996) and Düring et al. (2001) found two very different mitochon- 
drial haplotypes (ht) in Carabus splendens, which do not form a clade in the phylogenetic trees. One of these haplotypes is very similar to one found in C. punctatoauratus while the other is nearly identical to those found in C. rutilans. Both form a clade with these two species in the mitochondrial gene tree. The geographical distribution of both haplotypes was investigated by Düring et al. (2000). Ht1 is spread over the whole distribution area of the species while ht 2 is only present in some northern, isolated populations and in the western part, where it occurs in some populations together with ht 1 . As the most likely explanation of these results, an introgression event has been proposed, which involves the transmission of a complete mitochondrial genome by horizontal gene transfer (Düring et al. 2000). In this case, the maternal inheritance of the mitochondrial genome leads to misinterpretations, because the phylogeny reflects the history of the genes and not the history of the species. In contrast to the mitochondrial genome, recombination dilutes simultaneously introgressed nuclear DNA in the population by backcrossing. If our introgression hypothesis is correct, gene trees based on mitochondrial and nuclear DNA sequences should be different. In order to verify the proposed introgression hypothesis we analysed DNA sequences of the fast evolving nuclear internal transcribed spacer 2 (ITS 2). Possible incongruity between the placements of the taxa should allow conclusions about the underlying reticulate evolutionary processes.

\section{Material and methods}

DNA sequences of the ITS 2, including parts of the 2.0S rRNA, 5.8S rRNA and 28S rRNA, were determined via PCR and direct sequencing from the following Chrysocarabus species: Carabus splendens Olivier, 1790, C. lineatus Chevrolat, 1837, C. lateralis Chevrolat, 1840, C. auronitens Fabricius, 1792, C. punctatoauratus Germar, 1824, C. rutilans Dejean, 1826 and C. hispanus Fabricius, 1787. Carabus (Macrothorax) morbillosus DeLapouge, 1899 was included as the outgroup. The analysis included three specimens of Carabus splendens, which carry the three different mitochondrial haplotypes ht1, htla, and ht2. DNA sequences were deposited in the GenBank database (Acc. Numbers DQ683169DQ683178).

DNA was extracted with the commercial QIAamp tissue kit (QIAGEN). PCR amplification and primer sequences (ITS3 and ITS4) were specified in White et al. (1990). Direct sequencing was done on an $\mathrm{ABI}$ 373A sequencer using the Dye Terminator Cycle Sequencing Ready Reaction Kit (Applied Biosystems). Sequence alignment was done with the program ClustalX (Thompson et al. 1997). The full data set consisted of 664 sites (52 variable, 21 parsimony informative, outgroup included). After gap sites and parts of uncertain homology were removed, the data set finally consisted of 636 characters (v: 49 , p. i.: 18). For data analysis, we applied the parsimony method (MP) using PAUP* 4.0b10 (Swofford 1998) to allow a strict comparison with the published $\mathrm{CO} 2$ data. Additionally, calculations with the maximum likelihood method (ML, PHYLIP 3.6, with empirical base frequencies, transition/transversions $=1: 2$, and global rearrangements; Felsenstein 2004) were performed. The support of the branches was checked by bootstrap analysis (1,000 pseudoreplicates) and decay index (MP only). Both data sets (with and without gaps) were analysed by ML.

\section{Results}

The analysed data set without alignment gaps contains 26 variable and 17 phylogenetically informative positions within the ingroup. Sequence divergences (p-distance) are shown in Table 1. No substitutions were observed in the ITS 2 sequences ( $\mathrm{p}$-distance $=$ zero) between the individuals of Carabus splendens, which contain the three different mitochondrial haplotypes (ht1, ht1a, ht2).

Phylogenetic analysis using parsimony of the ITS 2 DNA sequences resulted in two most parsimonious trees (54 steps). The strict consensus tree is shown in Fig. 1. All three specimens of C. splendens containing the mitochondrial haplotypes ht1, ht 1a, and ht 2 cluster on a single branch. They form a clade with $\mathrm{C}$. lineatus/C. lateralis, which is supported by a high bootstrap value of 96\%. The Chrysotribax species (C. rutilans and 
Table 1. Sequence divergences in Chrysocarabus taxa. Nucleotide differences are given as percentage of divergence (lower left part based on nuclear sequences of ITS 2, upper right part from Düring et al. (2001) based on mitochondrial CO2 DNA sequences).

\begin{tabular}{|c|c|c|c|c|c|c|c|c|c|c|}
\hline & \multicolumn{3}{|c|}{ C. splendens } & \multirow[b]{2}{*}{ lin } & \multirow[b]{2}{*}{ lat } & \multirow[b]{2}{*}{ auro } & \multirow[b]{2}{*}{ punc } & \multirow[b]{2}{*}{ rutil } & \multirow[b]{2}{*}{ hisp } & \multirow[b]{2}{*}{ mor } \\
\hline & ht1 & ht1a & ht2 & & & & & & & \\
\hline splendens ht1 & - & 0.58 & 5.53 & 5.39 & 5.53 & 5.82 & 1.16 & 5.53 & 3.78 & 8.44 \\
\hline splendens ht1a & 0.00 & - & 5.39 & 5.39 & 5.53 & 5.97 & 1.16 & 5.39 & 4.08 & 9.02 \\
\hline splendens ht2 & 0.00 & 0.00 & - & 0.87 & 1.16 & 6.70 & 5.82 & 0.15 & 7.42 & 9.61 \\
\hline lineatus & 0.63 & 0.63 & 0.63 & - & 0.58 & 6.49 & 5.82 & 1.02 & 7.57 & 9.17 \\
\hline lateralis & 0.63 & 0.63 & 0.63 & 0.00 & - & 6.70 & 5.97 & 1.31 & 7.57 & 9.46 \\
\hline auronitens & 1.73 & 1.73 & 1.73 & 2.04 & 2.04 & - & 6.26 & 6.84 & 6.55 & 9.17 \\
\hline punctatoauratus & 1.73 & 1.73 & 1.73 & 2.04 & 2.04 & 0.31 & - & 5.82 & 3.78 & 9.02 \\
\hline rutilans & 2.67 & 2.67 & 2.67 & 2.99 & 2.99 & 1.89 & 1.89 & - & 7.42 & 9.75 \\
\hline hispanus & 2.36 & 2.36 & 2.36 & 2.67 & 2.67 & 1.26 & 1.26 & 1.26 & - & 9.32 \\
\hline morbillosus & 5.03 & 5.03 & 5.03 & 5.35 & 5.35 & 4.87 & 4.87 & 5.35 & 5.35 & - \\
\hline
\end{tabular}

C. hispanus) are grouped together with a moderate bootstrap value $(85 \%)$ and form a clade with C. auronitens and C. punctatoauratus $(75 \%$ bootstrap value).

The ML method resulted in a similar tree (Fig. 2). The three $C$. splendens haplotyes form a separate clade. C. rutilans builds a branch with $C$. his-

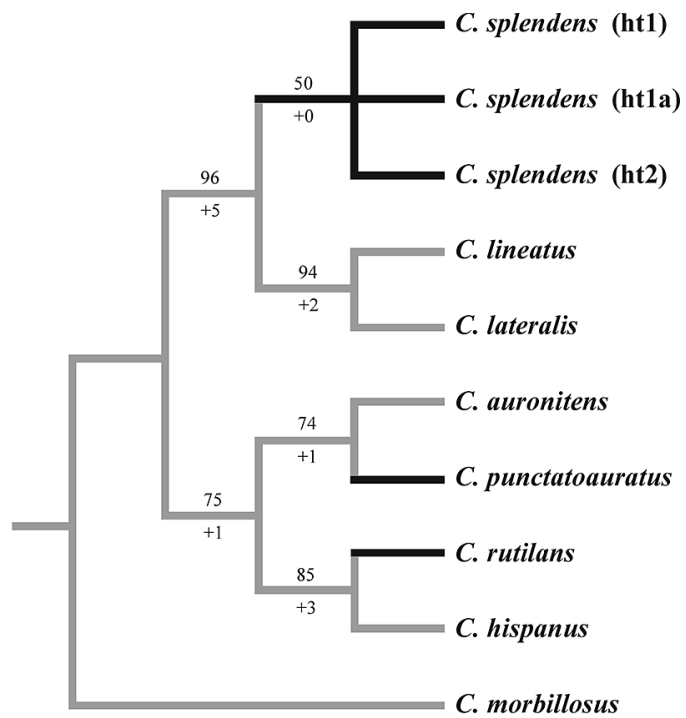

Fig. 1. Strict consensus tree of two MP trees (54 steps) based on nuclear ITS 2 DNA sequences of Chrysocarabus species. Bootstrap values (above line) and decay indices (below) indicate support of the nodes. Black bars mark the taxa mentioned in the introgression hypothesis. panus and C. punctatoauratus with $C$. auronitens, respectively. These clades are supported by high bootstrap values. The results of the data set which includes gaps are very similar. The boot-

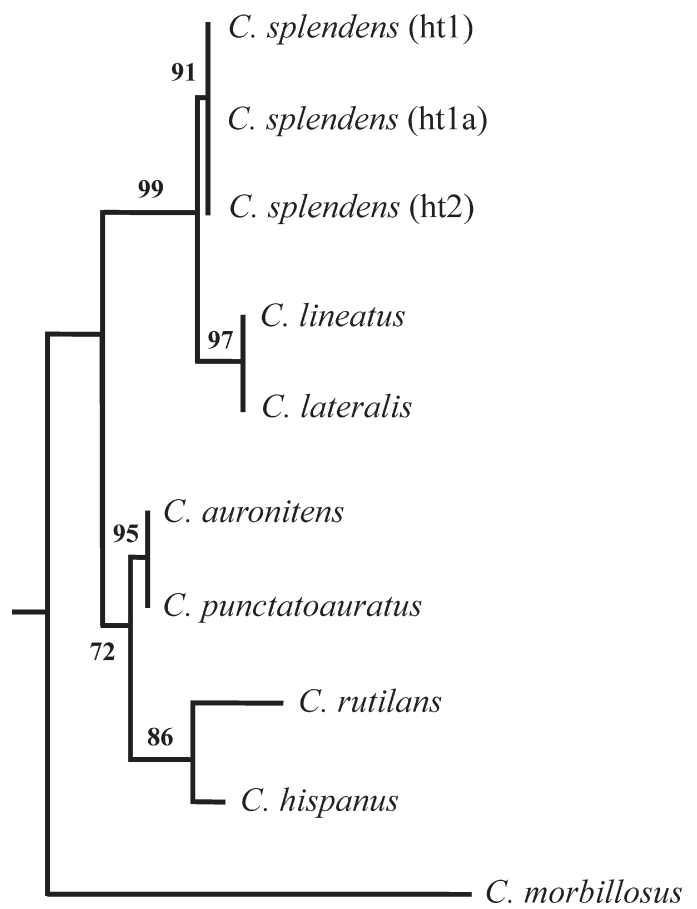

Fig. 2. Maximum likelihood tree based on ITS2 sequences of Chrysocarabus species. Numbers indicate branch support by bootstrap values (1,000 pseudoreplicates). Ln likelihood: -1204.27981. 
strap support of both analyses do not differ significantly with the exception of the branch which connects $C$. auronitens/punctatoauratus and $C$. hispanus/rutilans. This is about 10 percent points higher (results not shown).

\section{Discussion}

\subsection{Comparison of nuclear and mitochondrial gene trees}

The phylogenetic analysis of the ITS 2 DNA sequences by parsimony results in moderate to well supported branches (Fig. 1). Several of these branches contrast with the results of former phylogenetic analyses based on mitochondrial DNA sequences of the $\mathrm{CO} 2$ gene, although the DNA was isolated from the same individuals (Düring et al. 2001; see Fig. 3). The maximum likelihood analysis (Fig. 2) of the ITS 2 data resulted in a tree similar to that of Figure 1, the branches of which are supported by high bootstrap values. In particular, the branch of most interest (C. splendens, lineatus and lateralis) is well supported.

The lack of base substitutions in the nuclear DNA sequences between the individuals of C. splendens, which carry the mitochondrial ht 1 , ht $1 \mathrm{a}$, and ht 2 , is remarkable because it clearly demonstrates the monophyly of this species. C. splendens seems to be the sister taxon to C. lineatus/C. lateralis in the ITS 2 gene tree as well as in morphological studies (e.g., Mossakowski 1979). This is in contrast to the genetic distances of approximately $5 \%$ in the mitochondrial CO2 gene (Table 1) where the mitochondrial haplotypes of $C$. splendens are spread over the phylogenetic tree. In the mitochondrial gene tree ht1 and htla form a clade with $C$. punctatoauratus while ht 2 is grouped together with C. rutilans.

Additionally, in the nuclear gene tree, C. rutilans and C. hispanus form a sister group. This is in accordance with the classical morphological taxonomy where both taxa are described as Chrysotribax. However, this well established group is not found in the mitochondrial gene tree. The species $C$. auronitens and $C$. punctatoauratus, which were sometimes considered to be

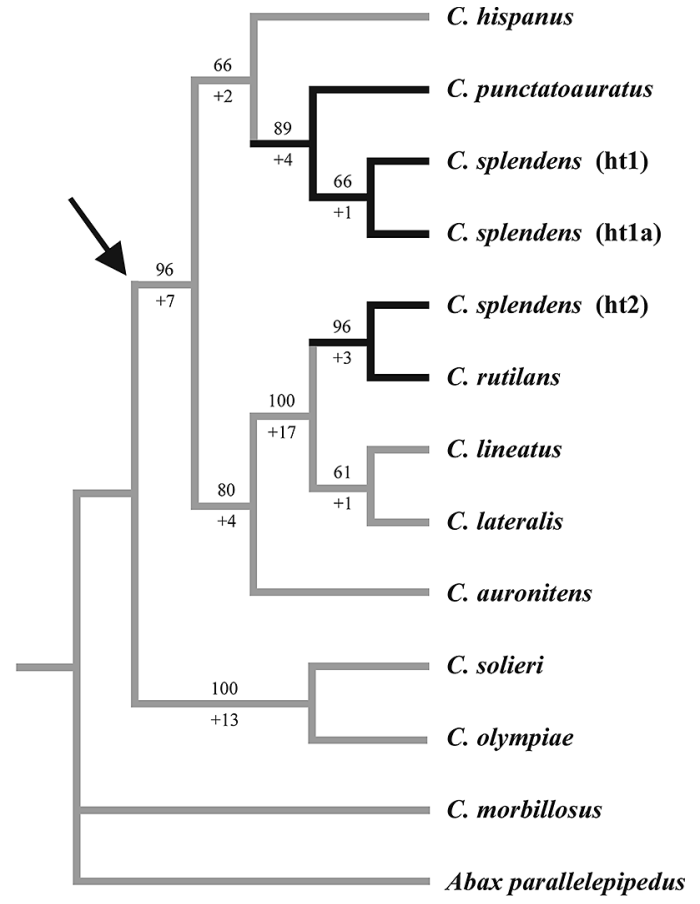

Fig. 3. Phylogenetic tree based on mitochondrial $\mathrm{CO} 2$ DNA sequences of Chrysocarabus species (after Düring et al. 2001). Bootstrap values (above line) and decay indices (below) indicate support of the nodes. Black bars mark the taxa mentioned in the introgression hypothesis. Arrow: see Discussion, section 4.2 .

subspecies, also form a clade in the ITS 2 gene tree (p-distance 0.31), although this grouping is not present in the $\mathrm{CO} 2$ gene tree. Only the sister group relationship of $C$. lineatus and $C$. lateralis is present in both the nuclear and the mitochondrial gene tree. However, these species are sometimes discussed as being conspecific (Allemand \& Malausa 1984).

The nuclear gene tree corresponds with morphological results and cross breeding studies, thus this tree may be interpreted as the organismal tree. The terminal branches of our tree have also been found by Sota and Ishikawa (2004) who studied the phylogenetic relationships within Carabus by means of two nuclear genes. Six of seven species of the inner group of Chrysocarabus (Fig. 1, without $C$. lateralis) resulted in the same pairs of sister species. But no resolution was found between these pairs. Additionally, the positioning of the mitochondrial haplotypes of $C$. 
splendens conflicts with the interpretation of the mitochondrial gene tree as the species tree (Düring et al. 2001).

\subsection{Introgression or ancestral polymorphism?}

Different phylogenetic trees inferred from independently inherited genetic markers, such as nuclear and mitochondrial DNA sequences, can be the result of convergence, pseudogenes (mitochondrial genes transferred into the nuclear genome), gene duplication, ancestral polymorphism or introgression (Maddison 1997). However, high homoplasy content was not found in the mitochondrial and nuclear DNA data sets of the Chrysocarabus subgenus. In addition, no evidence for pseudogenes, e.g., differences in the length of the PCR amplificates, unreadable base positions, indels, or stop codons (Zhang \& Hewitt 1996), was found in the mitochondrial DNA sequences.

If the existence of ancestral polymorphism (or gene duplication) is proposed to explain the differences between the mitochondrial and the nuclear gene tree, the two haplotypes (ht1/htla and ht2) of $C$. splendens must have been present in their last common ancestor in the mitochondrial tree (see the arrow in Fig. 3). This split can be dated using reference values of evolutionary rates of the mitochondrial genome. However, for a valid determination, only the genetic divergence of a taxon pair can be used which splits at the same time as the haplotypes of $C$. splendens. Two taxa, viz. C. hispanus and C. lineatus (or C. lateralis), fit this condition in both the mitochondrial and the ITS 2 gene tree. The sequence divergence in the mitochondrial data set is $7.6 \%$. Assuming a divergence rate of $2 \%$ per million years in the mitochondrial genome (Brown et al. 1982), this split is approximately 3.8 myrs old. Lower divergence rates have been proposed for carabids by Prüser \& Mossakowski (1998), Su et al. (1998), Brückner (2002) and Düring (2004), and for cicindelids by Barraclough and Vogler (2002). Therefore, this split may be slightly older, but probably not more recent.

Consequently, the ancestral polymorphism of the last common ancestor (see arrow in Fig. 3) should also be at least 3.8 myrs old. However, the sequence divergence is $0.15 \%$ between $C$. splendens ht 2 and $C$. rutilans and $1.16 \%$ between $C$. splendens ht1/1a and C. punctatoauratus. These genetic distances are too low to support this hypothesis. The events which lead to the different gene trees must have occurred much more recently. Therefore, ancestral polymorphism and gene duplication are unlikely explanations for the different gene trees.

\subsection{Introgression in Chrysocarabus}

According to the arguments mentioned above, the differences in the results of the phylogenetic analyses of mitochondrial and nuclear gene trees are most likely the result of introgression. The following scenario with at least two introgression events explains the major differences between the mitochondrial gene tree and the organismal tree:

(1) C. splendens (ht2) transferred its mitochondrial genome to $C$. rutilans by introgression, leading to their closer relationship in the mitochondrial $\mathrm{CO} 2$ gene tree. Consequently, the $\mathrm{CO} 2$ data set contains no non-introgressed (= no original) mitochondrial genome of $C$. rutilans.

(2) The mitochondrial genome of $C$. splendens (ht1) was acquired by introgression from $C$. punctatoauratus, followed by diversification into two subtypes (ht1 and htla).

However, the different position of $C$. auronitens in mitochondrial and nuclear gene trees suggests further potential introgression events which cannot be resolved by the available data sets.

The introgression of mitochondrial genomes by hybridisation requires a sympatric existence of the species involved. This was recently the case in C. splendens (ht1) and C. punctatoauratus (Fig. 4), but not in C. splendens (ht2) and C. rutilans. In accordance with the current distribution areas, the transfer of the mitochondrial genome from $C$. punctatoauratus to $C$. splendens seems a more recent event than the corresponding transfer from C. splendens to $C$. rutilans. However, this hypothesis conflicts with the genetic distances in the mitochondrial data set in which the genetic dis- 
Figure 4. Distribution area and haplotypes of Carabus splendens. Modified after Düring et al. (2000). Ht1 is spread over the whole area while ht 2 is only present in some northern isolated populations and in the western part where it occurs in some populations together with ht1.

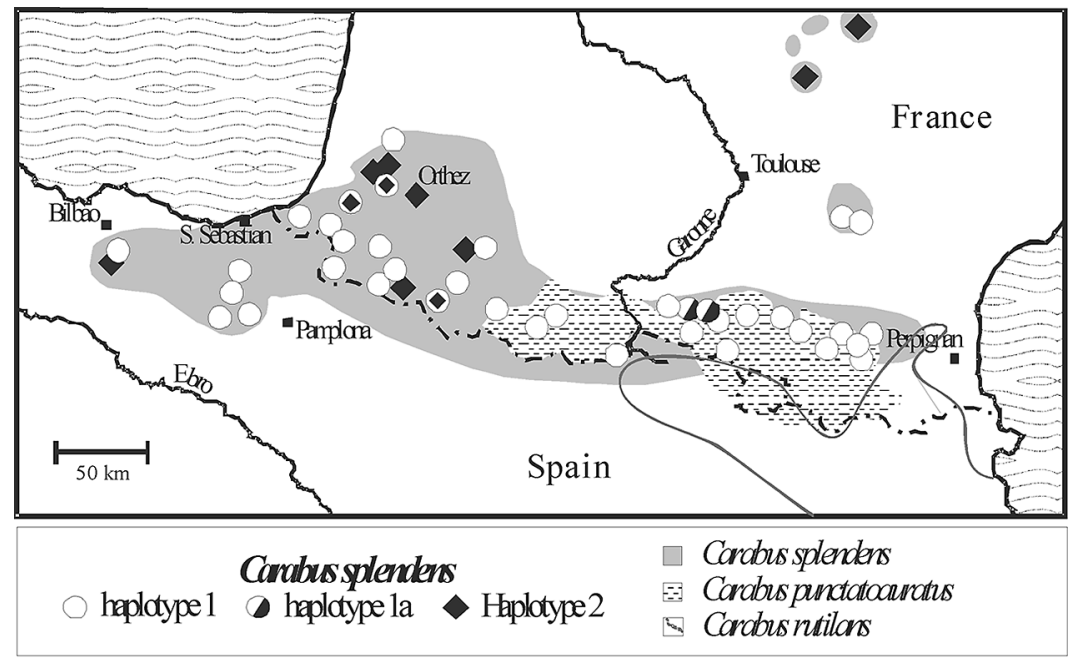

tance between C. splendens (ht1) and C. punctatoauratus is higher $(1.16 \%)$ than between $C$. splendens (ht2) and C. rutilans $(0.15 \%)$. Nonetheless, the distribution areas of both taxa have certainly changed after the last introgression event due to the quaternary climate fluctuations. The conflict between the genetic and distribution data is probably the expression of these area dynamics in Chrysocarabus.

In conclusion, our analyses point out a serious problem that may occur when gene trees are uncritically interpreted as species trees. Recently separated taxa with incomplete genetic isolation are potentially able to transfer genetic material if they experience a secondary contact. In regard of the maternal inheritance of the mitochondrial genome, these gene transfers will lead to misinterpretations, as we have demonstrated in the subgenus Chrysocarabus. Therefore, the analyses of different character complexes such as mitochondrial and nuclear genes or molecular and morphological characters, is a suitable way to obtain well established organismal trees and to reveal the underlying molecular evolutionary processes.

Acknowledgements. We would like to thank Dr. M. Vicker for English revision, and two anonymous referees for their helpful comments.

\section{References}

Allemand, R. \& Malausa, J.-C. 1984: Compatibilité génétique et distances phylétique entre les espèces du genre Chrysocarabus Thomson (Col., Carabidae). - Ann. Soc. Ent. France (N.S.) 20: 347-363. [In French.]

Barraclough, T. \& Vogler, A. P. 2002: Recent diversification rates in North American tiger beetles estimated from a dated mtDNA phylogenetic tree. - Mol. Biol. Evol. 19(10): 1706-716.

Braun, S. 1988: Verwandtschaftsanalyse bei naheverwandten Chrysocarabus-Arten (Coleoptera, Carabidae) mittels elektrophoretischer Untersuchungen. Mitt. Dtsch. Ges. allg. angew. Ent. 6: 548-559.

Brown, W. M., Prager, E. M., Wang, A. \& Wilson, A. C. 1982: Mitochondrial DNA sequences of primates: tempo and mode of evolution. - J. Mol. Evol. 128: 225-239.

Brückner, M. 2002: Phylogenie und Biogeographie der Gattung Percus Bonelli 1819 (Coleoptera, Carabidae): Eine molekularsystematische Analyse. - Academic thesis, University of Bremen. 245 pp.

Düring, A. 2004: Molekularsystematische Untersuchungen am Carabidentaxon Abax Bonelli 1810 (Coleoptera, Carabidae): Eine phylogenetische und phylogeographische Studie. - Academic thesis, University of Bremen. 363 pp.

Düring, A., Brückner, M., Zimmermann, M., Bobenhausen, I.; Eicke, N. \& Mossakowski, D. 2000: Geographic distribution of two highly different mtDNAhaplotypes in Carabus (Chrysocarabus) splendens Olivier. - In: Brandmayr, P. et al. (eds.), Natural History and Applied Ecology of Carabid Beetles: 5-9. Pensoft Publishers, Sofia, Moskow.

Düring, A., Brückner, M. \& Mossakowski, D. 2001: Differenzen zwischen gene tree und organismal tree? Mitochondriale Gene und die Verwandtschafts- 
beziehungen der Chrysocarabus-Arten. - Entomologica Basiliensia 23:93-98.

Felsenstein, J. 2004: PHYLIP (Phylogeny Inference Package) version 3.6. - Distributed by the author. Department of Genome Sciences, University of Washington, Seattle.

Maddison, W. P. 1997: Gene trees in species trees. - Syst. Biol. 46 (3): 523-536.

Malausa, J.-C., Raviglione, M. C. \& Boggio, F. 1983: Il Carabus olympiae SELLA dell'alta Valle Sessera. Pro Natura Biellese, Biella. [In Italian.]

Marciniak, M. 1995: Strukturen des Genitalapparates als Charaktere zur Rekonstruktion der Phylogenese bei Carabus-Arten. - Diplomarbeit, University of Bremen. 123 pp.

Mossakowski, D. 1979: Evolution of habitat preference illustrated by the phylogeny of Chrysocarabus species (Coleoptera, Carabidae). - In: den Boer, P. J. et al. (eds.), On the evolution of behaviour in carabid beetles: 103-122. Misc. Papers Landb. Hogesch. Wageningen 18 .

Mossakowski, D. \& Roschen, A. \& Vaje, S. 1986: Hybridization in Chrysocarabus. - In: den Boer, P. J. et al. (eds.), Carabid beetles: Their adaptations and dynamics: 281-295. Fischer, Stuttgart.

Mossakowski, D., Braun, S. \& Roschen, A. 1990: Hybridization in natural populations of ground beetles (Coleoptera, Carabidae). — Can. J. Zool. 68: 1783-1789.

Prüser, F. 1996: Variabilität mitochondrialer DNASequenzen und die Phylogenie der Gattung Carabus Linné 1758 (Coleoptera, Carabidae). — Academic thesis, University of Bremen. $173 \mathrm{pp}$.

Prüser, F. \& Mossakowski, D. 1998: Low substitution rate in mitochondrial DNA in mediterranean carabid beetles. - Insect Molecular Biology 7(2): 121-128.

Puisségur, C. 1964: Recherches sur la génétique des Cara- bes. — Vie et Milieu Suppl. 18: 1-288. [In French.]

Sota, T. \& Ishikawa, R. 2004: Phylogeny and life-history evolution in Carabus (subtribe Carabina: Coleoptera, Carabidae) based on sequences of two nuclear genes. — Biol. J. Linn. Soc. 81: 135-149.

Sota, T. \& Vogler, A. P. 2001: Incongruence of mitochondrial and nuclear gene trees in the carabid beetles Ohomopterus. - Syst. Biol. 50(1): 39-59.

Su, Z.-H., Tominaga, O., Okamoto, M., Omaha, T., Kajiwara, E., Ishikawa, R., Okada, T. S., Nakamura, K. \& Osawa, S. 1996: Parallel evolution in radiation of Ohomopterus ground beetles inferred from mitochondrial ND5 gene sequences. - J. Mol. Evol. 43: 662671.

Su, Z.-H., Tominaga, O., Okamoto, M. \& Osawa, S. 1998: Origin and diversification of hindwingless Damaster ground beetles within the Japanese islands as deduced from mitochondrial ND5 gene sequences (Coleoptera, Carabidae). — Mol. Biol. Evol. 15(8): 1026-1039.

Swofford, D. L. 1998: PAUP*. Phylogenetic Analysis Using Parsimony (*and other methods), Version 4. Sinauer Associates, Sunderland, Massachusetts.

Thompson, J. D., Gibson, T. J., Plewniak, F., Jeanmougin, F. \& Higgins, D. G. 1997: The ClustalX windows interface: flexible strategies for multiple sequence alignment aided by quality analysis tools. - Nucleic Acids Res. 24: 4876-4882.

White, T. J., Bruns, T., Lee, S. \& Taylor, J. 1990: Amplification and direct sequencing of fungal ribosomal RNA genes for phylogenetics. - In: Innis, M. A. et al. (eds.), PCR Protocols - A guide to methods and applications: 315-322. Academic Press Inc., San Diego.

Zhang,D. X. \& Hewitt, G. M. 1996: Nuclear integrations: Challenges for mitochondrial DNA markers. - TREE 11(6): 247-251. 